\section{Fænomenologi og topofili}

Filosofisk-poetologiske overvejelser over kroppen, billedet, stedet og teksten

Britta Timm KNudsen

Ud fra en bistoriefilosofisk betragtning kan det ikke undre, at rummet synes at have erstattet tiden. Det er længe siden vi opgav troen på historiens lykkebringende udvikling. Det synes rigtigt at hævde som også Michel Foucault gør det - at vi lever $i$ en rumepoke, hvor det er termer som simultanitet, sideordning (frem for underordning), forholdet mellem det spredte og det samlede, forholdet mellem fern og nær, der har erstattet de tidsorienterede katecorier. Den vending fra tid til Torien Alain 作 dernismens litterase historie med essaysamlingen $P d$ vej mod en ny roman, men det er som om det forst er nu, at vi kulturelt er på hojde med den udvikling. Globalisering (via økonomi, massemedier, osv.), folkevandringer og deraf følgende kulturel hybridisering er nogle af de fænomener, der kendetegner vores tid.

Alt dette giver den postkoloniale kunst og teori sig af med at aftegne konsekvenserne af. Man kunne have som en (forsigtig) tese, at $i$ denne rummets epoke bliver stedet en vigtig kategori. Stedet er en konkret lokalitet, som vi indgår en spatial sansemæssig relation til og som sidan et udsnit af det storre rum. Stedet og kroppen bliver da de koof af store reordinaDen fan for Den franske forfater Jean-Phlppe Toussaint er en forfatter, der har et interessant forhold til steder. Hvem husker ikke hans debutroman fra 1985, Badevarelset? Til sin kærestes undren yndede hovedpersonen at befinde sig i sit badeværelse, nærmere bestemt nede i sit badekar. I et forsøg på at gå i ét med elementet vand. Det er aldrig eksotiske rum, der har Toussaints interesse, men helt profane steder: bade- værelser, køreskolekontorer, fotomaskiner, benzinstationer, biler, telefonbokse.

Det komiske er, at det normalt er steder, vi opholder os ganske kortvarigt; transitsteder, der ikke sig selv normalt gøres til genstand for yderligere tankevirksomhed endsige æstetisk kontemplation, men steder, der opfylder en praktisk funktion; steder man lynhurtigt forlader igen.

Disse steder bebor heltene $\mathrm{i}$ Toussaints romaner Disse stect beta ofte nærine rum. For at kin dete og for nærme mig diskussionen af rum generelt 1 litteraturen er det nødvendigt med en teoretisk digression. Jeg vil først og fremmest ty til perceptionsfænomenologien og der finde belæg for en måde at beskæ tige sig med rum på $\mathrm{i}$ tekster, der både tager højd for, at tekster er sprog, og samtidig påpeger hvorledes den rumlige erfaring $i$ og af tekster udvider det udelukkende sproglige parameter, vi har arvet fra strukturalismen.

Krop, blik og billede

Perceptionsfænomenologien sætter tre ting på dags-

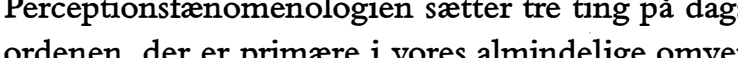
ordent der er primerverigennem verden efares (hvilket er noget andet end at sige verden udelukkende forstås gennem sproget). Herved fremkommer der en forskel mellem erfaring og forståelse, der er virksom i perceptionsfænomenologien. Det betyder, at vi i forste omgang har et umiddelbart forhold til verden. Hvad betyder det? Det betyder ikke (nødvendigvis) at den verden vi sanser umiddelbart behøver at kunne kategoriseres som en berørt naturverden, men derimod at den verden vi anser umiddelbart er vores verden (og ikke en eller anden fremmedgørende anden-verden). Den anden ting perceptionsfænomenologien peger på er nemlis det forhold, at krop og verden er tæt forbundne. Kropserspektivet er for ropsperspeliver en (a) ler rum. Perceptionsfenomenolon er saledes en rum-fænomenologi. ${ }^{x}$

Perceptionsfænomenologien skifter det bevidsthedsfilosofiske subjekt ud med en sansende krop, der først og fremmest ser og lever sin verden et bestemt sted fra. Kroppen er dermed sat i et perspektivisk udgangspunkt. Perspektivet er her både det, som vi nedarver fra kulturen (ikke alle perspektiver er mulige på et bestemt givet historisk tidspunkt), men samtidig er det også skabt. Merleau-Ponty udtrykker dette ved hele tiden at pege på det uafgorlige mellem om verden elsisterer eller den er forelige mellen oresillet. Det er des ha kalder kis commer verder til projicerer jeg mit blik ud struere den?

Man kan godt sige, at perceptionsfenomenologien er en slags perspektivisme i og med, at synserfaringen sættes som primær i vores forhold til verden. For Merleau-Ponty er perspektivet ikke blot givet eller nedarvet (hvad der ville betyde at måden at se verden på er forudskikket); kroppen er en del af perspektivet og som sådan en del af den iagttagne verden, men der produceres forskelle $i$ selve den indfoldning, ${ }^{2}$ der sker af kroppen i perspektivet. Perspektivet er både det der gor kroppen til subjekt sektivet er dide det dobjek (perspet veres af per (denle gor han på alle niveauer i ovrigt). Jeg ser igennem perspektivet, men samtidig med at jeg er seende er jeg også synlig eftersom min krop er en del af den iagttagne verden. Man kan udtrykke det pà denne màde: jeg ser igennem perspektivet og gør det jeg ser til mit, men samtidig ses jeg pa af perspektivet, der i den forstan fungerer som et kameraøje, der objektiverer mig fordi mit perspektiv blot er et udsnit af det store perspektiv.

Hvad er det da, der lader sig se gennem perspektivet? Et billede af verden. Om dette billede kommer indera eller udefra er altso uafrorligt, if Merleu-Ponty, men pointen er oso at ethul ifølge Mench ig

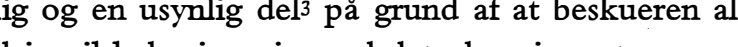
drig vil lade sig noje med det, der gives at se, men altid vil spørge, hvad der gemmer sig bag ved det synlige. Den beskuende krop er altså ikke kun defineret ved det, som viser sig, men også ved det, som forbliver skjult. Jacques Lacan arbejder med dette som et vilkår for synsbegæret: dels at begære de former, der viser sig, men også at begære det, som ikke viser sig, som holdes skjult.4

Den usynlige pol er vigtig, for den kan gøres æstetisk virksom og blive til et slags udspring for bilde kan transformere

Foreløbig kan vi altså sige, at perceptionsfænomenologien henleder vores opmærksomhed på to vigtige forhold $i$ kroppens synsmæssige erfaring af verden: for det første det at kroppen umiddelbart er en del af den iagttagne verden. Det vil sige, at vi som lroppe er henvist til de rum, vi gebærder os i. Fo det andet at det billede, som viser sig i den anden ende af perspektivet på den ene side oscillerer mellem at være givet og skabt, på den anden side indeholder det billede, der viser sig (det synlige), ogsà potentialer (det usynlige) til uendelige formdannelser.

Det litterere perspektiv

For at disse overvejelser skal blive interessante for littera disse overen krop, verden, rum og billeder som kategorier kan gores virksomme på et tekstniveau. For en umiddelbar betragtning er det selvfelgelig altsammen noget der er tilstede $i$ enhver litterær tekst, men spørgsmå let er, hvorledes vi kommer fra et fænomenologisk niveau til et tekstniveau. Man kan vælge at se helt bort fra problemet og arbejde med tekstverdene som om de var verdener eller tekstkroppe som or de var kroppe. Der er forskel på i hvor høj grad en 
tekst fremstiller sig som rum - man kan sige, at tekster, der er stærkt verdensmalende og deskriptive samt lidet narrative skærper vores interesse for verdensbilleder $i$ tekster. Samt kroppes sansemassige forhold til disse verdener - enten leserens ecen lop foller tels vep - eller terden.

Visse scener i Gustave Flauberts Madame Bovary er fortalt med en betydelig distance af en fortæller, der sætter sig højt op over sine personer. Dette perspektiv knyttet sammen med en bestemt deskriptionsteknik gør, at den tekst bliver til billeder, man kan opleve æstetisk fra en vis afstand. Deskriptionsteknikken har været læst som en teknik, der er ude på at distancere læseren fra den fremmalede verden. ${ }^{6}$ Men man kunne også hævde - helt i fænomenologiens ånd - at deskriptionerne i teksterne netop på grund af deres. billedkarakter i hojere grad involverer læseren som beskuer af den fremmalede verden. Netop fordi verden forst og frent af subjetet Netop ford

I den berømte karetscene (Flaubert, s. $299 \mathrm{ff}$ igennem Rouens gader, hvori Emma befinder sig sammen med Léon, kan man sige, at Flaubert - med kareten - danner et tekstligt billede, der på én gang er fladt, på én gang en uendelig projektionsflade for læserens forestillinger. De tekstlige figurer er forsvundne i scenen - de er blot til stede som stemmer, der udstøder ordrer fra karetens dyb - det er blot rammesætningen, der er afbildet. Med dette lille tekstbillede kommenterer Flaubert selve læsesituationen og dens indbyggede ,illusionsmageri“: $\operatorname{det}$ tekstlige rum har samme egenskaber som et realt rum, vi kan imaginert fylde det ud, men ogsi dets rum, vi kn ing sats (a) sat rundt on ingenting eller ries

Det er tydeligt, at perspektivismen filosofisk har en vis grad af berøring med synsvinkelspørgsmålet $i$ litteraturen. Hele spørgsmålet hvor noget er set og fortalt fra og graden af involvering $i$ det fortalte. I Jean-Paul Sartres modernistiske hovedværk Kvalme er der iscenesat en helt, der nægter at tage de foreliggende perspektiver på sig og som derfor heller ikke kan få sig sit eget perspektiv. Hovedpersonen
Roquentin er heri så fremmed og fremmedgjort over for verden, at han ikke kan identificere sig med noget, end ikke sit eget spejlbillede.7 Udsigten til blot at skulle overtage de andres perspektiv på verden giver helten kvalme og det opleves som friheds berøvende og fremmedgørende.

Sartre peger selvklart po fihedens problem i fe Sarem i feltaf

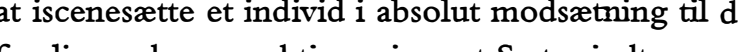
foreliggende perspektiver viser, at Sartre indtager en "position de survol" ${ }^{\text {i }}$ forhold til verden. Mennesker er henviste til de horisontale perspektiver, men man mindst skal være en engel 9 for at kunne indtage et hojttlyvende vertikalt. Det er ikke fordi MerleauPonty ikke mener man godt kan hæve sig op ove perspektiverne, der vil bare for Merleau-Ponty være tale om en relativ transcendens over for Sartres absolutte transcendens. Når Roquentin nægter at genkende sig selv i spejlbilledet, er det en benæotelse af ksistens middbe (a) velo verke wærk og derfor er det nærliggende at læse spejlscenen netop som krystalliseringen af den modernistiske avantgardes idé om at skabe sig selv pà baggrund af en fornægtelse af traditionen. Man kan tale om en fornægtelse af altings givethed og en tro på muligheden for at skabe alt påny.

Synsvinkelspørgsmål har at gøre med rumlig organisering $i$ det hele taget kan vi sige, men de kan også have med det at gøre helt eksplicit i og med at synsvinkèlperspektivet er kædet sammen med den konkrete spatiale organisering af teksten.

Det sker blandt andet $i$ den ny romans tekster. Det vi ter a den allerkendeste af disse tekster. Dis Alain netop at sandoynliggore et fenomenologisk perspektiv. En typisk strukturalistisk læsning af den roman - og en sådan har Roland Barthes beriget os med - fremlæser Robbe-Grillets æstetiske bestræbelse som én, der forsøger at fremstille verden uden mennesket. Som en kritik af subjektivismen og bevidsthedsfilosofien bygger Robbe-Grillet sit rum op $i$ analogi med New Science-bevægelsen og de strik formalistiske bestræbelser i det kubistiske maleri
Det Robbe-Grilletske blik er et blik, der bryder solidariteten mellem menneske og ting, hedder det hos Barthes, og længere væk fra en fænomenologi, der netop betoner forbundetheden mellem menneske og tingsverden, kan man ikke komme.

Men man kan fint læse Jalousi som en roman, der iscenesæetter sin hovedperson som et perspektiv midt $i$ en verden, han overhovedet ikke har styr på: en verden fyldt med synligheder og usynligheder og en verden fyldt med synligheder og usynligheder og en verden, der objektiverer synsvinkelbæreren. Rummene i Robbe-Grillets romaner forsøges beskrevet med stor analytisk-æstetisk distance og kølighed, men det er rum, der hele tiden er på nippet til at "overmande" den beskuende. Det er tydeligt, at synsvinkelbæreren i Jalousi (der mistænker sin kone for utroskab og som leder efter synlige beviser på sin hypotese) forsøger at holde det omgivende rum fra livet med sit distancerende blik. Men det er ligesà tydeligt, at det ikke lykkes.

Med den stærke deskriptivitet i rumfremstillingen liver rume til billeder - stillilled - folen Mer ber-billeder $i$ ovrigt har. "De skulle jo forestille at være billeder af det kendte (huset, haven, den umiddelbare nærhed), men de forlenes med en mystisk andethed. En andethed, der netop fremtræder fordi teksten har billedkarakter. Det er da i den udstrakning at teksten er som et billede, netop at den får karakter af at ville fremstille andetheden, det som sproget ikke kan rumme.

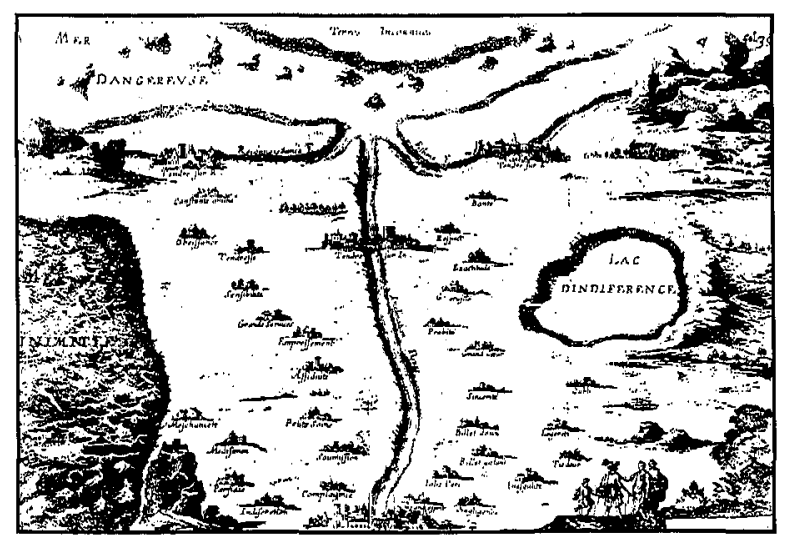

Billedet og verden

Der er især to træk, jeg vil fremhæve i forhold til den Merleau-Pontyske perceptionsfænomenologi og dens forhold til rum: for det forste det forhold at kroppen befinder sig $i$ umiddelbar nærbed med verden fra forte ford og det er dete nather den fra fof der ka akiveresi Billedet ligger hinsides den sproglige/lingvistiske organiseringsmodus. Billedet er hverken udtryk for et subjekt eller aftryk af en verden, men noget mid imellem. $V_{i}$ aktiverer vores forestillingsevne i møde med verden sådan så det. billede, vi danner i vores hovede, er resultatet af to bevægelser: sansning og kreativitet. Men det er vigtigt at påpege, at billedet udgør et mødested mellem subjekt og verden. Billedet befinder sig i mellemfeltet, l'entre-deux, det mellemfelt, som Merleau-Ponty benævner kødet, la chair.

Dette mellemfelt er vigtigt for at komme til en forstålse af, hvad en æstetisk erfaring er. I mellemfelteter og dét er kenen i den astetiske effaring. Det høre med til en fænomenologisk erfaringshorisont, at vi både er kropssubjekter og kropsobjekter. I den $\mathfrak{x}$ tetiske erfaring drejer det sig om at nå hen til en umiddelbar nærhed med verden, sådan så vi erfare os selv som et stykke (af) verden, samtidig med at vi erfarer verden i sin umiddelbare nærhed og tilstedeværelse. Her i Vivian Sobchacks citat: „...som de dybe og pludselige erkendelse man subjektivt kan fâ af objektiviteten, af materiens (selv vores egen) ,for-sig-selv-hed“, der rækker langt ud over vores forsøg på at inddæmme den" "r 2 (s. I6).

Man an Man kan sige at kroppens nærhed med verden fo et percptionsfanomenologisk perspektiv er grredvilar - verden er sanseligt thengelig for kroppen - men for at denne umiddelbare erfaring skal gøres viksom for en astetisk betragting $m$ man have med, at denne umiddelbarhed kommer ti stede gennem en middelbarhed - lad os bare kald det det poetiske billede. 
Det poetiske billede

Gaston Bachelard anvender udtrykket det poetiske billede. Og Bachelards billedbegreb er interessant, fordi det ikke er metaforen han er ude efter når han siger billede, men det er netop forsilling siger billede, men det er netop forestillingskraften evne til at dachelard projekt er amber en ,forestillingsevnens fænomenologi“ "og finde ud af hvilke helt grundlæggende billeder, vores fantasi består af Dette indebærer bl.a. en undersøgelse af de fire elementer som strukturerende for de billeder, som forestillingsevnen kan danne. Det er ikke Bachelards projekt som sådan, der interesserer mig her, men netop termen poetisk billede.

Bachelard adskiller forestillingsevne og perceptionen ligesom Sartre. Når vi sanser, modtager vi det, som er; når vi forestiller os noget, er vi fri af de forste billeder, fri til at forandre billederne. Som Ba chelard siger $i$ indledningen til $l^{\prime}$ Air et les Somges: chelard siger ind hed anges "Man vil altid have at forestillingskraften er evne til at forme billeder. Men den bre snarere evnen til at deformere de billeder, som perceptionen har leveret". Hos Bachelard er der tale om en udforskning af forestillingsevnens kreative potentialer (som ho en del franske fænomenologer i $50^{\prime} \mathrm{erne}^{\mathrm{i}}$ øvrigt ${ }^{\mathrm{t} 3} \mathrm{og}$ altså ogsa hos Merleau-Ponty). For os $i$ en poststrukturalistisk æra kan det synes som et noget bedaget synspunkt, nu hvor vi omsider har lært, at kreativiteten ikke er noget, der sidder i hovedet og som uhildet projiceres ud på verden. Vi har jo lært, at kreativiteten sidder i sproget og dets uventede kombinationsmuligheder. Men det er faktisk her man kan se, at et fænomenologisk perspektiv er interessant i dag, fordi det representerer et alternativ til en sant $\mathrm{i}$ dag, fordi det repræsenterer et alternativ
retorisk/lingvistisk tilgangsvinkel til teksten.

retorisk/lingvistisk tilgangsvinkel til teksten.
Den fænomenologiske tilgangsvinkel til billedet foregår i sproget, men den peger på det i sproget, der ligger ud over sproget og som alligevel kan 'ses'. Bachelard er interesseret $i$ det receptionsmæssig aspekt, det poetiske billedes effekt på en læser. Han siger et billedes værdi måles på dets imaginære stràling. I mødet mellem læser og tekst skal der hels ske det, at læseren erfarer sin egen forestillingsevn som åben og nyskabende. Hvorledes det? Jo ved at det tilstedeværende billede $i$ teksten făr læseren til a tænke på et fraværende billede, ja endog igangsætter en hel eksplosion af billeder. Der er her ikke blo tale om, at teksten revitaliserer - eksempelvis - laserens barndom, men om en vækkelse af forestilingsevnens kreative kraft. Bachelard siger folgende om det eller de billeder, der iverksetter forestitanken, derfor hidrører poesien ikke til ånden, men til sjælen “

Prøv at høre det tætteste Bachelard kommer på en definition af, hvad et litterært billede er:

Et litterert billede er en betydning, der er ved at blive til; ordet - det gamle ord - får heri en ny betydning. Men det endnu ikke tilstrakkeligt: det litterære billede bør beriges af nyt dagdrømmeri. At betyde noget andet og få andre til at drømme anderledes, dette er de to funktioner, som det litterære billede har.

(l'Air et les Songes, s. 324).

Det poetiske billede aktiverer forestillingsevnen, så poesi og eksistens bindes sammen og peger fremad. De poetiske billeder er ikke identifikationsobjekter i snæver forstand, som man kan sidde og nikke gensnæver forstand, som man kan sidde og nikke gen-
kendende til, men de iscenesætter tilblivelser. Her kendende til, men de iscenesætter tilblivelser. Her
kunne vi finde belæg for at sige, at det er i teksters kunne vi finde belæg for at sige, at det er $i$ teksters
billedlag, at det specifikt æstetiske og nyskabende billedlag, at det specifikt æstetiske og nyskabende
ligger. Den skærm, hvorpå tilblivelserne udspiller ligger. Den skærm, hvorpå tilblivelserne udspiller
sig. Derfor kan vi reaktualisere fænomenologernes gamle interesse for det imaginære for mere præcist at kunne pege på $i$ hvilke sproglige lag det kreative måtte befinde sig.

Det litterære billede er polyfont og polysemantisk og det bedriver overdrivelsens kunst, hvorved det er dynamisk Uden overdrivelse kan livet ikke udvikle sig, vi må forestille os for meget for at bumne realsig, vi milliti dets exces.
sere nok. Billedets metamorfosiske kraft ligger altså

Et litterært billede kan ikke begribes konceptuelt: det kan kun forstås som en delt undren mellem digteren og læseren. Billedet $i$ teksten fremprovokerer billeder $\mathrm{i}$ læserens bevidsthed: det er både billeder af erindringsmæssig art, der er tale om, men også billeder, der går ud over forestillingsevnen, åbner den for verden. Dagdrømmen, som kunstværket dels er et resultat af, dels afføder, er ikke en dagdrøm, der afspejler hverken fortiden eller nutiden, men som ábner for de mange muligheder i fremtiden.

Det litterære billede åbner for en eksistentiel dimension: hvad kan jeg blive, og det sker ved at billedet så at sige er verdensabent. Det vil måske være lidt for floromvundent at sige, at subjektet bliver for floro rt fald kan man sige, at verden bryder igennem til subjektet os her er der tale om 'lykkelige' gennembrud.

Som jeg har nævnt tidligere hænger billedniveauet ofte sammen med en interesse for rum. Således også for Bachelard: $\mathrm{i}$ bogen Rummets poetik ( $P$ oétique de l'espace) undersøger han forskellige litterære billeder, der har med rum at gøre. Bachelards ambition var at grundlægge topoanalysen som en sammenkædning af psykoanalyse og fænomenologi. Topoanalysen fokuserer på visse litterære billeders stedslige egenskaber som et led $i$ et systematisk psykologisk studie af lokaliteterne $i$ vores intime liv. Det er helt evident, at Det er helt evident, at top Det vilige, at vi her hos Bachelard genfinder forbindligheden mellem krop og sted, nu blot i en udvidet udgave. Som Edward $\mathrm{Ca}$ sey formulerer det: ,Jo mere vi retter opmærksomheden mod psykens topoi jo mere indser vi at de helt modsat af hvad Kant, Bergson, James og Husserl hævder - ikke kun er funktioner af tidens udstrekning. Rum snarere end tid er den ,indre betydnings" form" (Casey s. 288-89). . $4^{4}$

Bachelard argumenterer for at psyken eller sjælen er et „receptakel“ for poetiske billeder, der vækker tidlige intense erindringer om de forste rum og vore oplevelse af disse. Huset er den konkrete lokalitet, han undersøger i rummets poetik.

Det poetiske billedes forhold til rum har da at gøre med to simultane, men modsatrettede bevægelser: én, der peger bagud mod erindringen om hjemmets rum (Bachelard afsøger hjemmets betegnelser: reden, skallen, osv. altså alle mulige representationer af huset) og én, der peger fremad mod verden og evnen til at føle sig hjemme i den så at sige. Det interessante $i$ topoanalysen - ud over det at den er grundlæggende fænomenologisk på alle niveauer er at den faktisk tematiserer stedet som kategori rummet. Eller rettere, den tematiserer stedets rela- tion til det omgivende rum. I Bachelards topoanalyse er der 4 konkrete træk:

r) Indenfor i forhold til udenfor. Den skelnen kan ikke reduceres til faste stedodve stant bragti bevagese. Indenfor er et fydende folnd med et udenfor via døre og vinduer.

2) Der er m.a.o. kontinuitet mellem indenfor og udenfor. Det at bebo indebærer faktisk en mange på grænsesættelse. Hjemmet er måske en borg, me det behøver ikke være et sted, der holder verden ude. Tværtimod. Vi bebor et værelse i huset og gennem det bebor vi verden.

3) Det at bebo et rum decentraliserer mig: jeg er ikke centrum i det omkringliggende rum, skønt jeg angiver en retning til tingene, også jeg er centreret af det rum, der omgiver mig.

4) At bebo et rum er en erfaring af en intim uendelighed: at vare $i$ et hus er ikke at fale, at man wendeshet inod en fendig yde verden; det a befret $i$ denct erfare sig selv $i$ den sore verd en miniature. "E værelse $i$ vores hjem erfares ikke som en begrænsning, det vil sige en geometrisk sat grænse. At bebo sadan et rum betyder at det tager plads $i$ os og at $v$ tager bolig $i$ hele huset og $i$ verden gennem dette (Casey s. 293).

Disse træk er åbenlyst fænomenologiske i og med, at de opererer med en chiasmatisk relation mellem jeg' et (kroppen) og stedet og også i og med den etablerede gensidighed sted og rum imellem: jeg kommer til rummet via stedet.

Topofilien bliver nærmest en naturlig konsekven af topoanalysen. Topofile steder står $\mathrm{i}$ konsekven indifferente steder. Topofien udfolder ince poeiske bilede, bus ment i lykkelige rum, i gunstigt valoriserede rum, hvori man foler spatial velvare. Intense poetiske billeder, de wækker erindringer om intense tidligere rum, hvor jeg'et eller kroppen har følt sig $\mathrm{i}$ kontinuitet med dé uden for det konkrete sted.

Det er klart, at både Merleau-Ponty med sin kropsfilosofi og Bachelard med sine billed- og rumovervejelser anlægger et komplet a-historisk syn pa rum, kroppe og billeder. Foucault påpeger dette i sin tekst $\mathrm{O} m$ andre rum, og han siger, at hvis man be- 
skæftiger sig med $y$ dre rum vil man finde ud af at selv rummet har en historie. Foucaults tekst er problematisk ${ }^{15}$ - det har mange påpeget, derfor vil jeg ikke gøre det - men Foucault forsøger at åbne op for en historisk analyse af hvilke forkkellige rum, der $k$ a være i den universelle rumerfaring. I teksten foresta to slags rum: utopier (ima foreslas to slags nu det præsentere pier (reelle rum, der præsenterer krise-rum elle grænserum, f.eks. æængslet, psykiatriske hospitaler, men også tidsakkumulerende rum: f.eks. museer og biblioteker).

Konklusionen på alt dette må være, at MerleauPontys og Bachelards filosofiske og poetologiske perspektiv viser sig at være gangbar mønt i udforskningen af tesen omkring den sen-moderne identite som én, der udfolder sig som en udveksling mellem stedet og kroppen. Men at det også er nødvendigt med et historisk rumlag i denne relation, der ellers er transhistorisk. De poetiske billeders afs $ø$ gning a forholdet mellem krop og starre rum sker igning forholdet mellem krop og større rum sker igennem
det, man kunne kalde historiske specifikke steder, såsom telefonboksen.

Telefonboksen som poetisk topos

Hovedpersonerne - som alle er jeg-fortællere Jean-Philippe Toussaints romaner ligner på sin vis hinanden: de har den samme stræben efter at blive usynlige socialt set. At barrikadere sig i sit badekar er et tydeligt udtryk for denne stræben. Jeg-personen længes efter en meditativ tilstand, hvor det er langsomheden og eftertænksomheden - den helt introverte tilstand - der er i højsædet. Denne tilstan har naturligvis med elementet vand at gore i Badeverelset. Badekarsvand, regnvand (p. 36, hvor jegpersonen længe spekulerer over visse hoor jegpersonen længe spekcrer over visse koncentrtionsevelor, der bestra $i$ at folge to regndrå vej ned ad ruden), vandet 1 Venedigs gad

Med Bachelard in mente kan vi sige, at Badeverelset som roman afsøger forholdet mellem jeg-personen og elementet vand. Elementet vand er knytte til tid og bevægelse på paradoksale måder: på é gang standses tiden og bevægelsen, pà én gang det et billede på tidens uendelige flow og bevægelsernes uophørlighed. Det er helt klart, at romanen forsøger at efterspore samhørigheden mellem individ og element hinsides den sociale verden. Ofte er den sociale verden i Toussaints romaner fremstillet farceagtigt. Det er slet ikke derhen personernes stræben går. Når jegpersonen i Badeverelset vil forsøge at være nogen, kigger han sig $i$ spejlet, men i spejlet, men

Den meditative vand-tilstand forsøges tilnærmet på forskellig vis. Feks. via kedsomhed, selvudelukkelse fra alt socialt liv (arbejdsliv f.eks.), udøvelse af profane zenbuddhistiske kunstarter (profane eftersom man $i$ zen udøver kunsten at skyde med bue og pil, hvilket i Badevarelset selvfølgelig bliver til kunsten at spille pilespil). Jegpersonen i Badevarelset skifter rum: tager fra Paris på en rejse til Venedig, men det farver ikke romanen med nogen særlig lokalkolorit (der er næsten ingen deskriptioner i den og som sådan næsten ingen verden). Rummene er på den måde underlagt sindet. Det er måske en eksistentialistisk roman vi har med at gore: måske endog en postmoderne variant af den modernistiske eksistentiche 作 alt for press badever af meditativ kedsomhed. Men denne tilstand satter vores, helt $i$ forbindelse med elementerne, altsà med en verden, der er 'større end' den sociale verden. En naturverden eller verden som et større kosmos.

Badevarelset er i sin komposition bygget op som en trekant - med tre dele, hvori de enkelte afsnit bærer talnumre - én del hedder endog hypotenusen. Jeg har nii aldrig kunnet få dimensionerne til at passe, men indtrykket af strikt form er bevaret (spejlscenerne spejler sig i romanen fra afsnit 23 i I. del til afsnit 32 i III. del). Romanen iscenesetter spendingen mellem den geometrike komposion

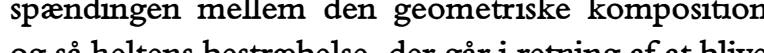
ets be pot ponere. Det billede kan jeg ikke lade vare med at læse meta-litterært: det er selve billedet pà kunstens bestræbelse i Bachelards forstand, men samtidig er det tydeligvis en roman, der behandler eksistensen. Og jeg-personen øver sig $i$ at være tilstede, når han er meditativ: øver sig $i$ at blive en regndråbe for derved at være $\mathrm{i}$ intens kommunikation med universet.
Han tænker ikke kun regndråben, han bliver den simpelthen

I Fotografiapparatet har vi ligeledes at gøre med en jeg-person, der søger sin identitet andre steder end i det sociale hurlumhej. Som titlen angiver er der ile om billeder, nemlig billeder af identiteten. Jes leter Jeggøre sig håb om det, sistentialistisk problem. På et tidspunkt befinder han sig om bord pà en bad mellem England og Frankrig og der finder han et fotografiapparat, og det give anledning til overvejelser over hvilket billede ha gerne ville tage af sig selv og hvad der ville være pà det billede.

Med det fotografiapparat, som jegpersonen finder om bord på båden, tages en lang række billeder. Sådan lyder det, når jegpersonen forestiller sig, hvordan han gerne ville have det til at se ud (udtrykt ved den conditionalis, der er anvendt):

fotografiet ville være udflydende men ubevægeligt, bevægelsen være standset, intet ville mere bevæge sig, hverken mit nærver eller fravær, den ubevægelighed, som går forud for livet og folger efter det, ville dér være til stede $i$ hele sin udstrakning, knap nok fjemere end himlen, som jeg havde for mine ejne.

(Fotografiapparatet s. 80)

Man kan sige han nærmest forestiller sig et billede af uendeligheden, af et jeg, der er gået i ét med universet. Senere da filmen er blevet fremkaldt ser det sådan ud:

Ikke ét af de billeder, jeg selv havde taget den nat, var blevet til noget, ikke et eneste, og da jeg omhyggeligt kiggede negativeme efter, blev jeg klar over, at fra det tolvte billede var filmen uafbrudt underbelyst, her og der med en uformelig skygge som et um rrkeligt spor af mit fravær. skygge som

Her er det fraværet, der er fotograferet. I stedet for at se dette som et tomrum eller negationen af identitet vil jeg vælge at se det netop som det egentlige. Jegpersonen søger et fravær eller en forsvinden væk fra den sociale verden ind $i$ en anden verden, hvor det netop er fraværet, der bliver det egentlige. Jeg vil prøve at se på topofilien i romanen, på forholdet mellem rum, billede og æstetisk oplevelse.

Toussaints romaner har en ironisk, næsten farcetig tone. Orså ofte selvironisk ger er et 列 (a) sig afted efter en ny flaske gas (hvad der bliver et uoverstigelig projekt, eftersom de fleste intentionelle handlinger løber ad absurdum): „Jeg lagde flasken $\mathrm{i}$ bagagerummet og tog plads ved siden af hende, idet hun startede (hvilket par, vi to, Herre du milde) “" (s. I8). I denne sætning ændres fokalisationen pludselig fra at være intern, hvor fokalisationen tildeles det erfarende jeg, til at være enten ekstern eller neutral. I den eksterne fokalisation kan fortælleren se begivenheder og personer fra et sted uden for handlingen ofte i retrospektiv.

Anvendelsen af datidsformen taler for at det er et synsvinkelskifte fra intern til ekstern fokalisation, der er tale om. Men der er også den neutrale fokalisation, hvor fortælleren treder ud af 'sin ham' så at sige og giver nogle oplysninger, som han aldrig ville have kunnet give, hvis han/hun var blevet inden det perciperende jeg. Sætningen viser et synsvinkelskifte til et objektiverende blik, men samtidig påkaldes herren som endnu et kommenterende lag til synsvinklen. Det er som om Toussaint i denne lille parantes får peget på synsvinklernes uendelige regres (bag ved mig står der endnu én og så videre). Eksemplet viser en bestemt spaltning i erfaringen: jeg lever, oplever og erfarer noget, men samtidig kan jeg også se mig selv. erfare noget.

Eksemplet viser metabevidstheden hos ethvert moderne menneske, men samtidig er der også eksempler på, at visse synsvinkler ikke (længere) kan indtages, fordi vore kroppe er forankret til et jordisk, begrænset perspektiv:

En helikopter floj lavt over os, og jeg gik og så op, alt imens jeg tænkte, at vi måtte være morsomme at se på, sådan som vi kom gàende her på stranden $i$ halen pà hinanden. (ibid. s. 47). 
Det skægge i dette eksempel er, at antydningen til det guddommelige perspektiv (det Merleau-Pontyske position de survol) sker gennem en helikopter. Her kan vi tydeligt se en anden strategi, som Toussaint ofte anvender, nemlig insisteringen på det profane. Også profane rum

\section{Rum}

På det store plan Paris, Milano, London. På det lidt mindre plan: køreskolens kontor, bilen, fodplejeinstituttet!, benzinstationen, restauranten, fotomaskinen, båden, telefonboksen. Jeg vil se nærmere på slutbilledet i romanen; det forestiller en telefonboks midt om natten på en øde landevej mellem Orly, Orléans og Paris. Dette billede i romanen er et ægte topos, hvor en topofili udspiller sig og samtidig er det brillant til at historisere den æstetiske erfaring med. I dette meget indskrænkede og på sin vis profane rum åbenbares noget. Man kan her tænke på det, Salman Rushdie engang har sagt:-16 Kan kunsten vere et tredie princip, som sag it ten varer mellem den 作 mask - ved at nyt - noget som måske endda kunne kaldes en verdslig definition af transcendens. For det er vel en sådan verdslig form for transcendens vi har at gøre med her.

Telefonboksen er et poetisk billede i Bachelardsk forstand og det er ydermere et billede af et rum. Telefonboksen og kroppen fusionerer til et perspektiv, der tillader og betinger en æstetisk erfaring af nærhed med verden, med kosmos. Boksen fungerer for jegfortalleren som et perspektiv, der tillader en kommunikation med universet, og for læeren er hele slutsekvensen netop et poetisk billede, hvorigennem den (verden som den for den (verden som den forligger for sansingen) og en skabt verden (det poetiske billede som et billeder skabt i sproget, men som peger ud over sproget). Telefonboksen bliver i Toussaints tekst til et sted, hvor der udtrykkes topofilt velvære. Der sker ganske enkelt en æstetisering af rummet $i$ den forstand, at det ikke længere opfylder sin funktion (som i snæver forstand er at kommunikere). Den kommunikation afbrydes - jegfortælleren har en mønt til- bage, ringer til sin kæreste Pascale og beder hende ringe op, hvad hun aldrig gør. Pă den måde fâr telefonboksen æstetisk egenværdi. Den anvendes til en kommunikation af mere universel art. Boksen bliver et kropsforlængende attribut, en skærm vend mod og i ly af den sociale verden, en skrom hror mod og ily af den so indenfor et and tænker sig et andet liv fin for aggression og smerte. Et idylisk liv. Men er der tale om en simpel modstilling mellem ydre og indre? Og er der i telefonbokse-billedet tale om en afbildning af forestillingskraftens evne til at forestille sig det, som ikke er som altid forestiller sig noget andet end det, som er, altså er der tale om en afbildning af forestillingskraftens produktive evne?

Tankeflugten foregår $\mathrm{i}$ et kulturelt frembragt rum og ikke netop direkte under Guds himmel. Jeg vil mene om denne passage, at den meget fint udtrykker kunstens evne til at metamorforisere kendte former og opfinde nye For hvad er det for et liv eller en anden realitet, som vores je fot liv eller sig: de jor sig: de jegfent som netop har opsogt de meditative rum? Altsà rystende former med utydelige bonturer........i en uendelig-

Jegfortælleren fastholder ojeblikket, som der står ,jeg så solen stå op og tænkte helt enkelt på nu'et“ (s. 88). Slutter i en sammenlignende og måske paradoksal metafor omkring det, at det er lige så svær at fastholde øjeblikkets nåde, som det er at få en sommerfulglevinge til at stå stille ved at spidde den med en nål: Romanen slutter med ordet „Levende“

Der er tale om et æstetisk sublimt øjeblik, som Toussaint verdsliggør ved at anvende telefonboksen som konkret historisk lokalitet. Den æstetiske erfaring, der opleves i det profane rum, benærnes med ordet nåde. Som netop er noget, der gives og ikke ordet nade. Som netop er noget, der gives og ikke noget, der skabes: ,jeg sà solen stã op og tænkte hel enkelt pâ nu'et idet jeg endnu engang prøvede at fastfryse dets flygtige nåde.." (s. 88). Telefonboksbilledet er på én gang et billede på intens kommunikation og forbindtlighed mellem krop og verden. dette paradoksale billede mellem indsnævring og udvidelse - dér viser formerne deres uendelige vá- riationsmuligheder. Jegfortælleren forestiller sig eller simulerer som der stä - et andet liv, hvor livets fylde i hvert ojeblik mærkes, hvor former i bevægelse gennemstrømmer hans bevidsthed. Men slutbilledet er også et skabt billede, der priser den kreative forestllingsevne ikke kun som individuel meditaiv laft men netop som den instans, due mediciv bentans, der skaber mulight komm Son keer bilde er telefonboksen en metafor for den kommunikation, der foregår igennem bogen som medium mellem en stemme og en anonym lytter. I den finaktion er bolsen narmest et a-topos, et ikke-sted eller et hvilket-som-helst-sted. Globalt og interkulturelt, interkommunikativt, et symbol på at der kan etableres fællesskaber på tværs af tid/sted/kulturelle og sociale forskelle. Via telefonboksen kan Toussaint få fremskrevet det essentielle i både et fænomenologisk og et æstetisk perspektiv. Nemlig betoningen af det relationelle: relationen mellem bop og sted og relionen mellem sted og mum. Relap og (a) mellen krop og vivet og skab perspektiv sadan som Metlean-Ponty lærer os det. Telefonboksen som topofilt sted er bade udtryk for en fænomenolgisk konkret verdenssansning, der kommer udefra til os (øjeblikket som nåde) og udtryk for et poetisk billede, der kan skabe og udvirke den samme slags sansning i leseren ved hjælp af sproget. Og via en ganske bestemt evne $i$ sproget. Nemlig sprogets evne til at skabe billeder, der på én gang er sprog og som peger ud over sproget. Bachelard sagde, at de poetiske billeder skulle være excessive for at virke og pegede dermed på de poetiske billeders form-ynglende kraft.

Den realitetet vores jegfortaller tenker frem beDir ike af lyde eller of else. Den best alse. Den besta ner ork eksisterer. Usynligheder (i Menleau-Pontysk forstand), der gøres æstetisk produktive gennem det poetiske billede. Verdener, der endnu ikke er til stede men som kommer til stede igennem det poetiske billedes paradoksale karakter af at være både givet og skabt.

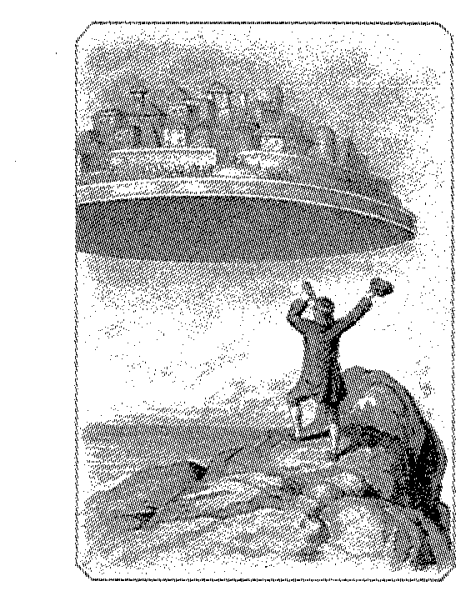

Den svevende 8 Laputa
Fra Jonatran Swrrt: Gullivers Reisen (Leipzig ca. 1910).

Litteratur

Bachelard, Gaston: L'Air et les songes: Essai sur l'imagination du monvement; Corti, Paris; 194

. Lautranont, Corti, Paris; 1939

Universitaires de France

Bryson, Norman: Looking at the Overlooked. Four Essays on Britain; 1990

Casey, Edward: The Fate of Place, A Philosophical History University of California Press, Berkeley, Los Angeles, London; 1997

Flaubert, Gustave: Madame Bovary; Gallimard, Paris; 1972 (r857)

Foucault, Michel: "Andre rum"; Slagmark 27, Vinter

Lacan, Jacques: Le Séminaire livre XI Les quatre concepts fondamentaux de la psychanalyse; Seuil, Paris; 1973 Paris; 1964

- Phénomenologie de la perception; Gallimard, Paris; 1945 Rushdie, Salman: Fantasiens hjemlande: essays og kritik 1981 . 91; Samleren, Kobenhavn; 1992

Sartre, Jean-Paul: La Nausée; Gallimard, Paris; 1938 Delard; Twayne Publishers, Boston; 1982

Sobchack, Vivian: „The Passion of the Material: ProlegoAngeles UCLA; 1993

Elisabeth Ströker: Philosophische Untersuchungen zum Raum

Vittorio Klostermann, Frankfurt; 1965

Toussaint, Jean-Philippe: L'Appareil-photo; Minuit, Pari $-988$ 
Noter

I. Over for den anden fenomenologiske retning $i$ dette ârhundrede, nemlig tidsfenomenologien, der begynder med Henri Bergson og som gar over 1 interessen for bestrukturalistiske gennembrud. Gilles Deleuze indterer her - efter min overbevisning - en serstatus, da hans tenkning forener tid og rum på en sofistikeret måde.

2. Indfoldning - er et begreb fra Gilles Deleuzes bog $L$ Pli: Leibnitz et le Baroque, Minuit, Paris I994. Jeg kan henvise til Jan Ifversens og min oversatelse af forste kapite af denne bog i en intern udgivelse pã Det Kongelige Danske Kunstakademi, Billedhuggerskolen, u.à.

3. Jvf. titlen på et af Maurice Merleau-Pontys hovedver4. Jacques Lacan: Les Quatre Concepts Fondamentaux de 1964 . 4. Jacques Lacan. Les af dette se Joan Copjecs artikel: „The Orthopsychic Subject: Film Theory and the Reception of Lacan" i Octobe 49, Cambridge 1994, hvori hun konfronterer denne lacanianske position med et foucaultsk perspektiv. Se i ovrige min lille artikel „Kroppen og synet", som er et diskuterende review af et foredrag Copjec holdt 1 Arhus november 1998, Cekvina Nyt, nr. I, 1999 i.p.

S.I Elsabeth Strokers bog Phlosophische Untersuchungen rummet $i$ atmosferisk rum, aktionsrum med en deling atmosferiske rum er det, som vi er en del af uden at tænke på, at vi er den del af det. Et umiddelbart rum, der omgiver kroppen: „Det atmosferiske rum er ikke 'uden for' mig; ligesom tingene omgiver det mig, det befinder sig rundt om mig.." (p. SI). Med det atmosferiske rum udtrykker Stroker den basale fænomenologiske erfaring nærhed med verden, som Merleau-Ponty omtaler, nàr han ikke kan open al so ", derimod - implicerer afstand. For det farste en ifstand tit tingene, der iagttages og en afstand til selvet, der også $\mathrm{kan}$ iagttages. For Ströker er det forst $i$ den distance, som tankerummet implicerer, at visualiteten kommer til at spille en rolle: „Synssansen er den vigtigste af sanserne, for den tillader den tænkende krop at betragte sig selv og forblive pà afstand fra sig selv." (p. roo)

6. Det drejer sig om en omvending af Georg Lukács' per-

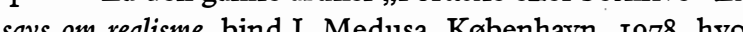
han taler om henholdsvis Tolstoj som narrativ og engage rende forfatter og om Flaubert som en deskriptiv og distancerende forfatter. Sporgsmalet er om billedet distancerer mere end sproget. Hvis man antager et mind ikonoklastisk syn på billedet, så må man sige, at med bil- ledet er vi i det intersubjektive felt - det er sporgsmål on identifikation, spejling, idealisering osv. der stiller sig dette felt. Og sporgsmidet on bild

7. Den beromte spejlscene, hvor Roquentin reflekterer ever sit eget spejlbillede, som han ikke kan se som
end mănekrater, s. 33-34 (i den franske udgave).

8. En ,position de survol" er en position, der mener

den analyserende og betragtende helt kan distancere sig fra det betragtede i stedet for at betragte en involverethed og en gensidig pãvirkning som central for forholdet mellem seende og set.

9. Romanforfattere kan indsatte engle $i$ deres romaner for at tydeliggøre niveauskiftet fra et menneskeligt, horisonet overskuende over-menneskeligt perspektiv. Jeg her på Merete Pryds Helles roman Men jorden stâr til evig tid fra 1996. Heri optrader der Engle, der svæver over byen, men disse engle er usynlige for de agerende personer og blot synlige for leseren. Englen er helt parallel til den implicitte fortaller, blot med den forskel, at englene eksplicit berører synsvinkelsporgsmal og perspektiver. Gad vide om det forhold, at det $-\mathrm{i}$ det moderne - er umuligt at inkarnere et vertikalt perspektiv, giver sig udslam en mon (og for ikke nodvendiovis som en nostaloisk langsel efter overskuelighed, men netop som et udtryk for at overskueligheden er virksom som forestilling

Io. Netop middelbarheden er det Jacques Lacan fremanalyserer som eksistensens grundvilkår i sin berømte spejstadieartikel fra 1949.

II. Norman Bryson: Looking at the Overlooked. Four Essays

I2. Vivian Sobchack: „The Passion of the Material: Prolegomenon to a Phenomenology of Interobjectivity", 1993 kring det imaginxere, imaginationen. Ud over de allerede næwnte (hvoraf Deleuze forer en frenomenologisk og on strukturalistisk inspiration sammen) frenomenologer er der både Cornelius Castoriadis og Roger Caillos, der knytter imagination og kreativitet.

14. Edward Casey har i bogen The Fate of Place, 1997, lavet en imponerende flosofhistorisk gennemgang af forholdet mellem Sted og Rum tibage fra de tidligste grakere ti nyere fransk flosefs,

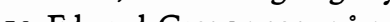

caults essay blandt andet det tablematiske punkter i Fouundergrave sin egen bistorisk prætention ved at hævde "heteropologiens universelle karakter" (s. 301 )

I6. Salman Rushdie (s. 276). 